\title{
A Demonstration That Large-Scale Warming Is Not Urban
}

\author{
DAVID E. PARKER \\ Hadley Centre, Met Office, Exeter, United Kingdom
}

(Manuscript received 14 March 2005, in final form 25 July 2005)

\begin{abstract}
On the premise that urban heat islands are strongest in calm conditions but are largely absent in windy weather, daily minimum and maximum air temperatures for the period 1950-2000 at a worldwide selection of land stations are analyzed separately for windy and calm conditions, and the global and regional trends are compared. The trends in temperature are almost unaffected by this subsampling, indicating that urban development and other local or instrumental influences have contributed little overall to the observed warming trends. The trends of temperature averaged over the selected land stations worldwide are in close agreement with published trends based on much more complete networks, indicating that the smaller selection used here is sufficient for reliable sampling of global trends as well as interannual variations. A small tendency for windy days to have warmed more than other days in winter over Eurasia is the opposite of that expected from urbanization and is likely to be a consequence of atmospheric circulation changes.
\end{abstract}

\section{Introduction}

There have been several attempts in recent years to estimate the urban warming influence on the largescale land surface air temperature record. Jones et al. (1990) found that the urban warming influence on widely used hemispheric datasets is likely to be an order of magnitude smaller than the observed centurytime-scale warming. Easterling et al. (1997) found that global urban warming influences were little more than $0.05^{\circ} \mathrm{C}$ century ${ }^{-1}$ over the period $1950-93$. Hansen et al. (1999) concluded that the anthropogenic urban contribution to their global temperature curve for the past century did not exceed approximately $0.1{ }^{\circ} \mathrm{C}$. Furthermore, they estimated the global average effect of their urban adjustment during $1950-98$ as only $0.01^{\circ} \mathrm{C}$ (see their Plate A2), though their adjustment procedure removed an urban influence of nearly $0.1^{\circ} \mathrm{C}$ in the contiguous United States in this period. Peterson et al. (1999) compared global temperature trends from the full Global Historical Climatology Network with a subset based on rural stations, defined as such both by map metadata and by nighttime lighting as detected by satellites. They found that the rural subset and the full set had very similar trends since the late nineteenth cen-

Corresponding author address: Mr. David Parker, Hadley Centre, Met Office, FitzRoy Rd., Exeter EX1 3PB, United Kingdom. E-mail: david.parker@metoffice.gov.uk tury, and inferred that the urban influence on the full set was therefore insignificant. Accordingly, only small systematic errors were ascribed to urbanization in the global warming trend estimates made by Folland et al. (2001a) and in the Intergovernmental Panel on Climate Change Third Assessment Report (IPCC TAR; Folland et al. 2001b).

Nevertheless, controversy has persisted. Following IPCC TAR, Hansen et al. (2001) upgraded the Goddard Institute for Space Studies (GISS) analysis and found that overall urban adjustments to data for the contiguous United States required since 1900 exceeded $0.1^{\circ} \mathrm{C}$ but that the adjustment differed according to the dataset used. Furthermore, adjustments for other changes such as observing time, siting, and instrumentation were typically as large as or larger than, and of opposite sign to, the urban adjustment. Kalnay and Cai (2003) used the difference between trends in observed surface temperatures in the continental United States and corresponding trends in the National Centers for Environmental Prediction-National Center for Atmospheric Research (NCEP-NCAR) reanalysis, which does not use the surface temperature observations, to infer $0.27^{\circ} \mathrm{C}$ century ${ }^{-1}$ surface warming due to land use changes since 1950. This was contested because the NCEP-NCAR reanalysis did not include cloudiness data and had errors in its surface heat budget (Trenberth 2004), and because the surface air temperature observations used by Kalnay and Cai (2003) had not 
been adjusted for heterogeneities such as changes of instrumentation or observing time (Vose et al. 2004). Subsequently, Zhou et al. (2004) used an improved version of the NCEP-NCAR reanalysis and a method similar to Kalnay and Cai (2003) to estimate $0.05^{\circ} \mathrm{C}$ decade $^{-1}$ urban warming in the winter during 1979-98 over southeast China where the surface air temperature data were found to be homogeneous in regard to instrumental and other nonclimatic changes. However, this urban warming was only about $10 \%$ of the total warming found by Zhou et al. (2004), and the authors point out that the urban warming effect will be smaller in summer owing to greater cloud cover. Simmons et al. (2004) were unable to find support for Kalnay and Cai's conclusions in the 40-yr European Centre for MediumRange Weather Forecasts (ECMWF) Re-Analysis (ERA-40), which had almost as much warming over the eastern United States near the $850-\mathrm{hPa}$ level as in the Jones and Moberg (2003) surface air temperature analysis. Furthermore, Peterson (2003) found no statistically significant impact of urbanization in an analysis of 289 stations in 40 clusters in the contiguous United States, after the influences of elevation, latitude, time of observation, and instrumentation had been accounted for. One possible reason for this finding was that many "urban" observations are likely to be made in cool parks, to conform to standards for siting of stations. Peterson and Owen (2005) noted that the type of metadata (population versus night lights) made significant differences to urban versus rural classification for stations in the United States, but that the omission of the stations classified as urban by both schemes (population >30 000 within $6 \mathrm{~km}$ ) made very little difference to the overall warming trend in the United States Historical Climatology Network (USHCN) since 1931.

The influence of urbanization on air temperatures is greatest on calm, cloudless nights and is reduced in windy, cloudy conditions (Johnson et al. 1991). Although the main effect of urbanization is on nighttime temperatures, there is some evidence of lesser effects by day (Arnfield 2003). Biases arising from poor instrumental exposure and micrometeorological effects are also likely to be greatest in calm, cloudless conditions, by day as well as by night (Parker 1994). The effects of solar and longwave radiation inside thermometer shelters, specifically the resulting temperature differences between thermometers, their housing, and the air, are minimized in windy weather (Lin et al. 2001). Time-ofobservation biases (Karl et al. 1986) are enhanced in calm, cloudless conditions when diurnal temperature ranges are large and reduced in windy, cloudy weather when diurnal temperature ranges are small.

Accordingly, an analysis of trends of worldwide land surface air temperature on windy, cloudy days and nights is most likely to be free of urban biases, and also to be less affected by the instrumental, siting, and procedural biases that had to be treated by Hansen et al. (2001) and Peterson (2003) in their analyses of urban warming. Comparison of such an analysis with trends based on all data may yield a new estimate of the size of the systematic errors to be accorded to urbanization in estimates of global warming over land. Instrumental measurements of wind strength at temperature observing stations are not generally available, but gridded near-surface wind components are available from the NCEP-NCAR reanalysis (Kalnay et al. 1996) on a 6-hourly basis since 1948. These near-surface winds are constrained by the generally reliable mean sea level pressure observations. Cloud observations at temperature observing stations are also generally unavailable, and the NCEP-NCAR reanalysis cloudiness data are highly model dependent (Kalnay et al. 1996).

Therefore, daily land surface air temperatures since the mid-twentieth century from a selection of stations worldwide have been analyzed separately for windy and calm conditions, as defined by the NCEP-NCAR reanalysis, as well as for the full sample, without stratifying by cloud amount. Section 2 presents the data and analytical techniques used. The results in section 3 cover both daytime and nighttime temperatures for the globe and a selection of large regions and are a substantial extension of the summary of the results published by Parker (2004). Section 4 discusses some additional comparisons and section 5 draws conclusions.

\section{Data and methods}

Daily station maximum $\left(T_{\max }\right)$ and minimum $\left(T_{\min }\right)$ temperature data for 1948 onward were obtained for the stations in Fig. 1a from the sources indicated. Figure 1a shows the benefits of improved availability of data from the Global Climate Observing System (GCOS), but major gaps remain in the Tropics (Mason et al. 2003). Smoothed (Jones et al. 1999) daily climatological averages of $T_{\max }$ and $T_{\min }$, for 1961-90 where possible ( $86 \%$ of stations), were created for each station, and anomalies calculated.

Daily average near-surface wind components were obtained from the NCEP-NCAR reanalysis (Kalnay et al. 1996) through the National Oceanic and Atmospheric Administration-Cooperative Institute for Research in Environmental Sciences (NOAA-CIRES) Climate Diagnostics Center (in Boulder, Colorado) Web site (see online at http://www.cdc.noaa.gov/cdc/ data.ncep.reanalysis.html). The wind components were converted to scalar speeds, which were used to classify 
(a)

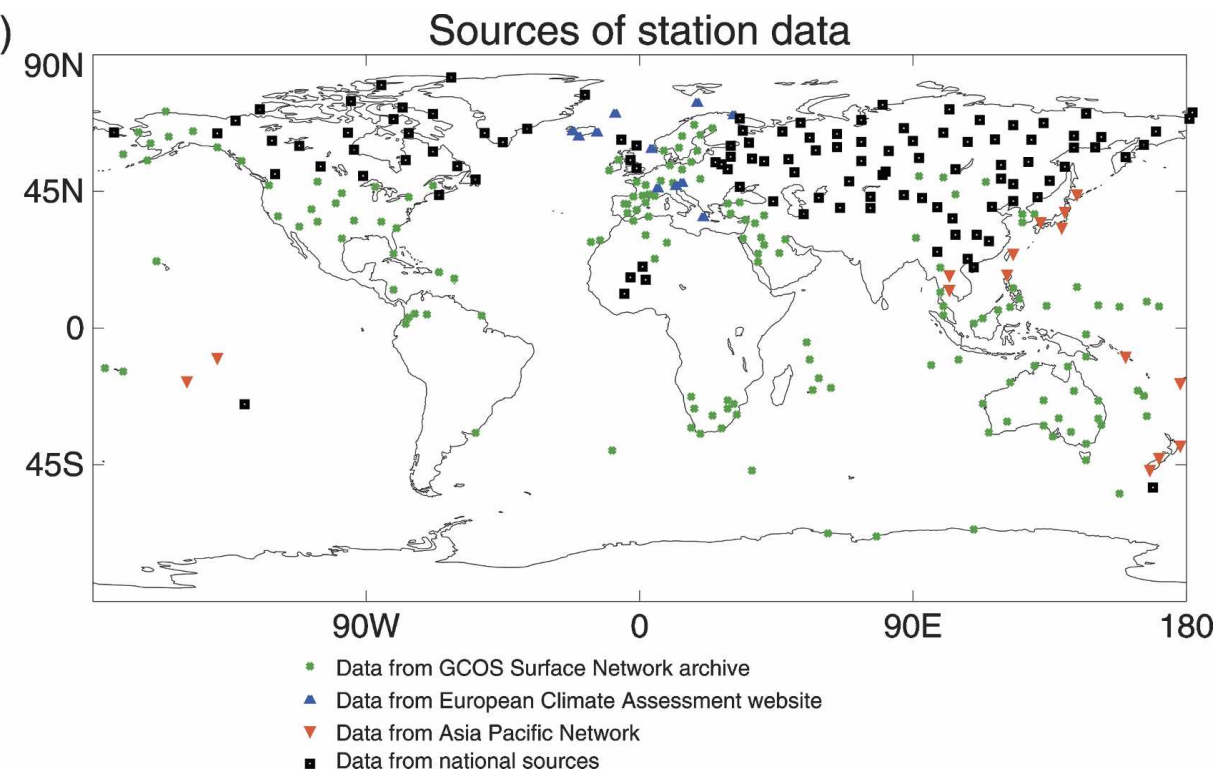

(b)

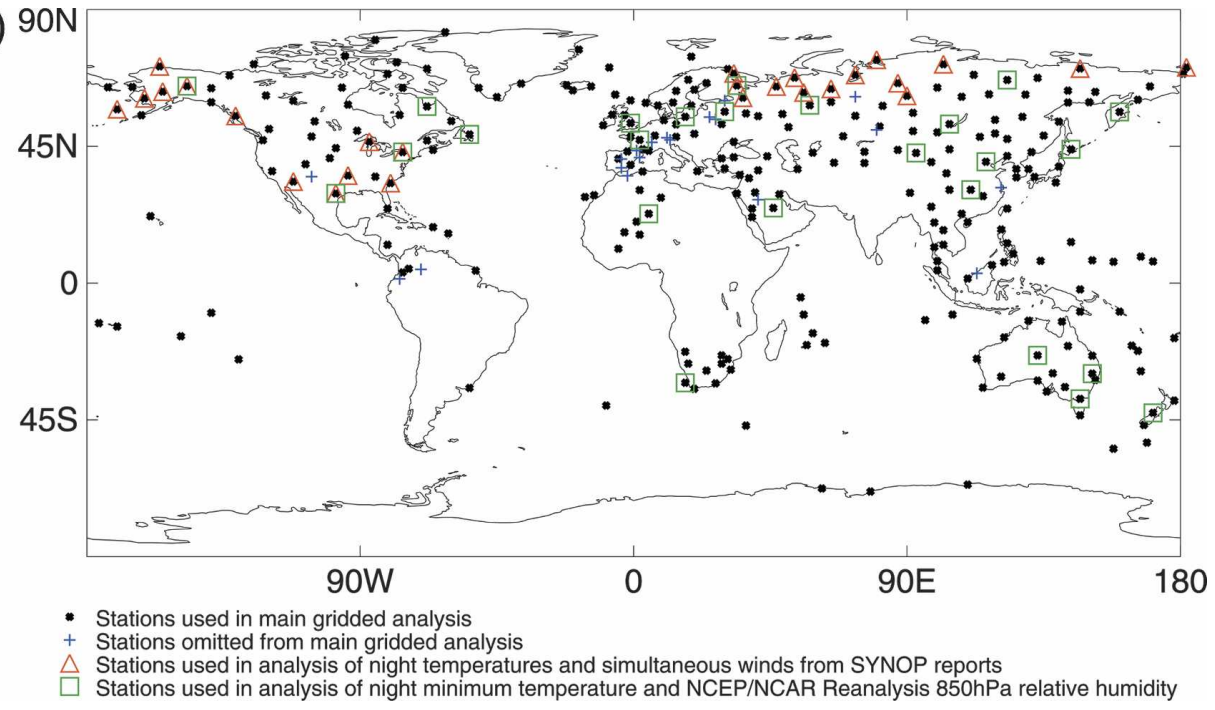

FIG. 1. (a) Sources of station data. Data were obtained from the GCOS surface network (GSN) archive at NOAA's National Climatic Data Center (Asheville, NC; dots), the European Climate Assessment (ECA) Web site (online at http://eca.knmi.nl/; Klein Tank et al. 2002; upward-pointing triangles), the APN dataset (Manton et al. 2001; downward pointing triangles), and several national sources (Parker et al. 1992; Parker and Alexander 2001; Laursen 2002; Razuvaev et al. 1993; Vincent et al. 2002; squares). (b) Stations used in the main and subsidiary analyses as described in the legend and main text.

each date at stations worldwide as "windy" or "calm." Even at night, when the coupling between the surface layers and the free atmosphere is most likely to be weakened, these daily average reanalysis wind speeds are generally sufficiently correlated with the limited available observing-station wind speeds for the purposes of this study (appendix C). Quantiles of the statistical distributions of wind speed were estimated for each day of the year, using gamma distributions (Horton et al. 2001). Each day's wind speed was then classified as calm (terce 1 unless otherwise stated) or windy (terce 3). Temperature anomalies were then matched to the appropriate date in order to assign them to speed classes. For stations between $140^{\circ} \mathrm{E}$ and the date line, $T_{\text {min }}$ (which most frequently occurs in the early morning) was matched with the previous day's speed. For 
stations between $120^{\circ} \mathrm{W}$ and the date line, $T_{\max }$ was matched with the following day's speed. Where countries ascribed $T_{\max }$ to the date of the morning when the instrument was read, rather than the date on which $T_{\max }$ occurred (appendix A), this was allowed for. Annual, half-year (October-March, April-September) and seasonal (December-February, etc.) temperature anomalies for windy days and for calm days were then compared for each station.

Figure 2 shows relative warming on calm nights at Fairbanks, Alaska, which is known to be affected by urban warming (Magee et al. 1999). Of the 290 stations studied, only 13 showed significant relative warming of calm nights (appendix B).

The annual and seasonal anomalies of $T_{\max }$ and $T_{\min }$ for each station in Fig. 1b marked with a dot (with or without a surrounding triangle and/or square) were gridded on $5^{\circ}$ latitude $\times 5^{\circ}$ longitude resolution for windy, calm, and all conditions. The 19 stations marked "+" were not used, generally because they shared a grid box with another station with a longer or more complete record. Only one of these showed urban warming (appendix B), implying minimal potential impact on any worldwide urban warming signal. In the gridding process, anomalies for all conditions (windy and calm) were omitted if there were 25 (5) or fewer applicable days' data in the year or season. Maps of the gridded anomalies of $T_{\min }$ for 1975 (Fig. 3) illustrate the spatial coherence of the fields, and the tendency for the windy (calm) nights to be relatively warmer (colder), especially in the extratropics. Coverage was at least 200 grid boxes in 1957-99. Global and regional averages for each year and season in the period 1950-2000 were calculated from the gridded data, with weighting by the cosine of latitude.

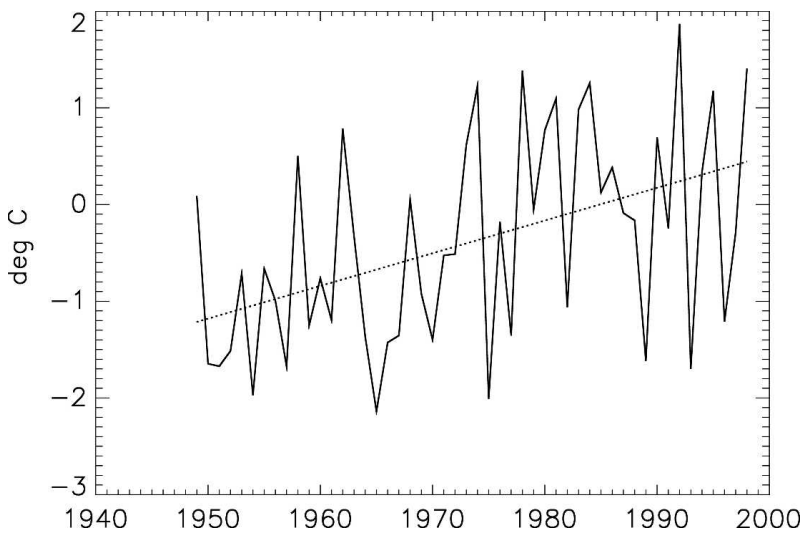

FIG. 2. Annually averaged $T_{\min }\left({ }^{\circ} \mathrm{C}\right.$, relative to 1961-90) at Fairbanks, AK, on calm relative to windy nights. The trend correlation is 0.46 and the restricted maximum likelihood (Diggle et al. 1999) linear trend of $0.34^{\circ} \mathrm{C}_{\text {decade }}^{-1}$ is significant at the $1 \%$ level.

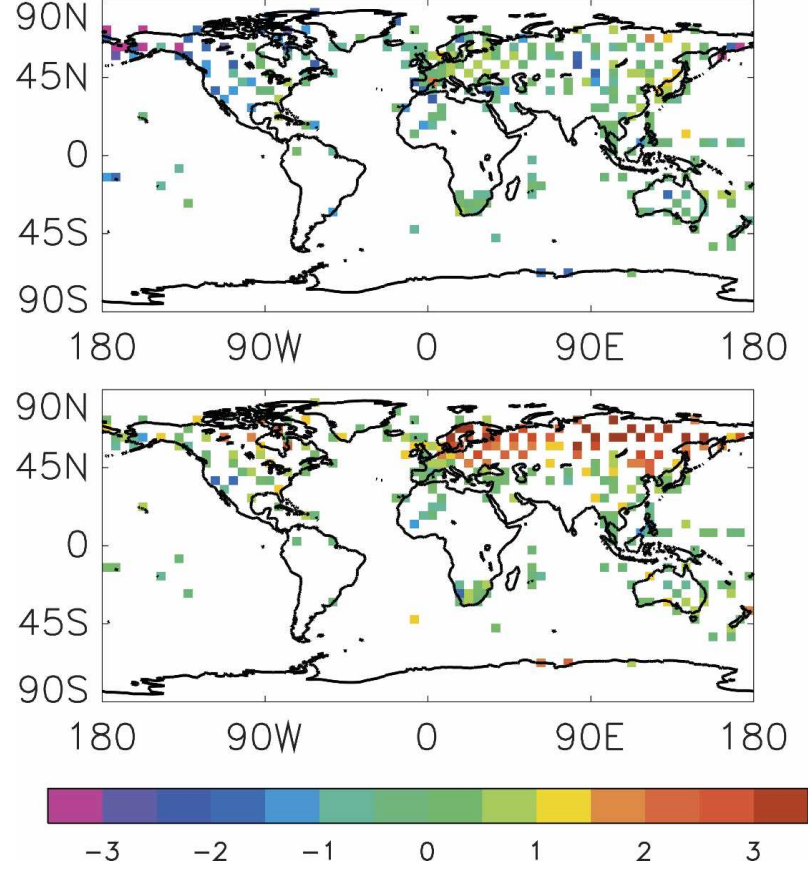

FIG. 3. Annual anomalies of $T_{\min }\left({ }^{\circ} \mathrm{C}\right.$, relative to 1961-90) on (top) calm and (bottom) windy nights in 1975 .

It is conceded that this method relies on the assumption that there are no systematic changes in atmospheric circulation during the period of analysis, other than those expressed as a change in calm and windy frequencies. Section 3 shows that this assumption does not hold in western Eurasia in winter. However, owing to the wide longitudinal distribution of stations in the extratropical Northern Hemisphere (Fig. 1), these effects are likely to cancel on a global scale; furthermore, section 3 finds no such circulation-induced effects in summer.

To assess the sensitivity of the analysis technique to differences between the NCEP-NCAR reanalysis daily average winds and the limited available observations of nighttime wind at the stations, the analysis was repeated on 26 stations in North America and Siberia (triangles in Fig. 1b) using routine observations of simultaneous, instantaneous nighttime temperature $\left(T_{\text {night }}\right)$ and wind. The nighttime observing hour was kept constant and as close to dawn as possible to coincide with the most usual time of $T_{\min }$. The data were obtained from the NOAA Integrated Surface Hourly Dataset, which holds data received in operational "SYNOP" messages through the Global Telecommunication System of the World Weather Watch. These station nighttime wind data were also compared directly with the NCEP-NCAR reanalysis daily average winds; results are summarized in appendix $\mathrm{C}$. 
Although the NCEP-NCAR reanalysis cloudiness data are highly model dependent (Kalnay et al. 1996), an analysis of $T_{\min }$ was carried out using daily average NCEP-NCAR reanalysis relative humidity at $850 \mathrm{hPa}$ $\left(\mathrm{RH}_{850}\right)$ as a proxy for low-level cloudiness over 25 stations (squares in Fig. 1b). There was no systematic tendency for "clear" nights to warm relative to "cloudy" nights, which would be a symptom of urban warming. However, at about a quarter of the stations, the time series of station $T_{\min }$ for clear minus cloudy nights showed discontinuities that were not evident in the analysis with respect to the NCEP-NCAR reanalysis surface winds. Also, the analysis failed to detect the known urban warming at Fairbanks, Alaska (Magee et al. 1999). Therefore, the 850-hPa relative humidities from the NCEP-NCAR reanalysis appear to not be a reliable classification tool for low cloudiness. Details of the analysis are in appendix D, where it is also shown that observed nighttime cloud cover data, while positively correlated with $\mathrm{RH}_{850}$, may be of insufficient quality to verify it.

\section{Results}

The main impact of any urban warming is expected to be on $T_{\min }$ on calm nights (Johnson et al. 1991). However, for 1950-2000, the trends of global annual average $T_{\min }$ for windy, calm, and all conditions were virtually identical at $0.20^{\circ} \pm 0.06^{\circ} \mathrm{C} \mathrm{decade}^{-1}$ (Fig. 4a,b and Table 1). When the criterion for calm was changed to the lightest decile of wind strength, the global trend in $T_{\min }$ remained $0.20^{\circ} \pm 0.06^{\circ} \mathrm{C}_{\text {decade }}{ }^{-1}$ (Fig. $4 \mathrm{c}$ ). So the overall analysis appears not to show an urban warming signal and to be robust to the criterion for calm.

In the supplementary analysis using simultaneous, instantaneous nighttime temperature, $T_{\text {night }}$, and wind at 26 stations (section 2), windy and calm nights warmed at the same rate: $0.20^{\circ} \mathrm{C}$ decade $^{-1}$ over the period 1950 2000. Over this period, $T_{\min }$ classified by the NCEPNCAR reanalysis winds over these 26 stations warmed by $0.29^{\circ} \mathrm{C}\left(0.21^{\circ} \mathrm{C}\right) \mathrm{decade}^{-1}$ for windy (calm) nights but the differences between windy and calm, and between $T_{\min }$ and $T_{\text {night }}$ trends, were not statistically significant. One reason for differences is that for some stations, $T_{\text {night }}$ data but not $T_{\min }$ data were available for 1999-2000. Trends over 1950-98 averaged over the 26 stations were $0.19^{\circ} \mathrm{C}$ decade ${ }^{-1}$ for $T_{\text {night }}$ for both windy and calm nights, and $0.26^{\circ} \mathrm{C}\left(0.23^{\circ} \mathrm{C}\right)$ decade $^{-1}$ for windy (calm) for $T_{\text {min }}$.

The global annual result conceals a relative warming of windy nights - the opposite of what would be expected from urbanization-in Europe $\left(35^{\circ}-70^{\circ} \mathrm{N}\right.$,
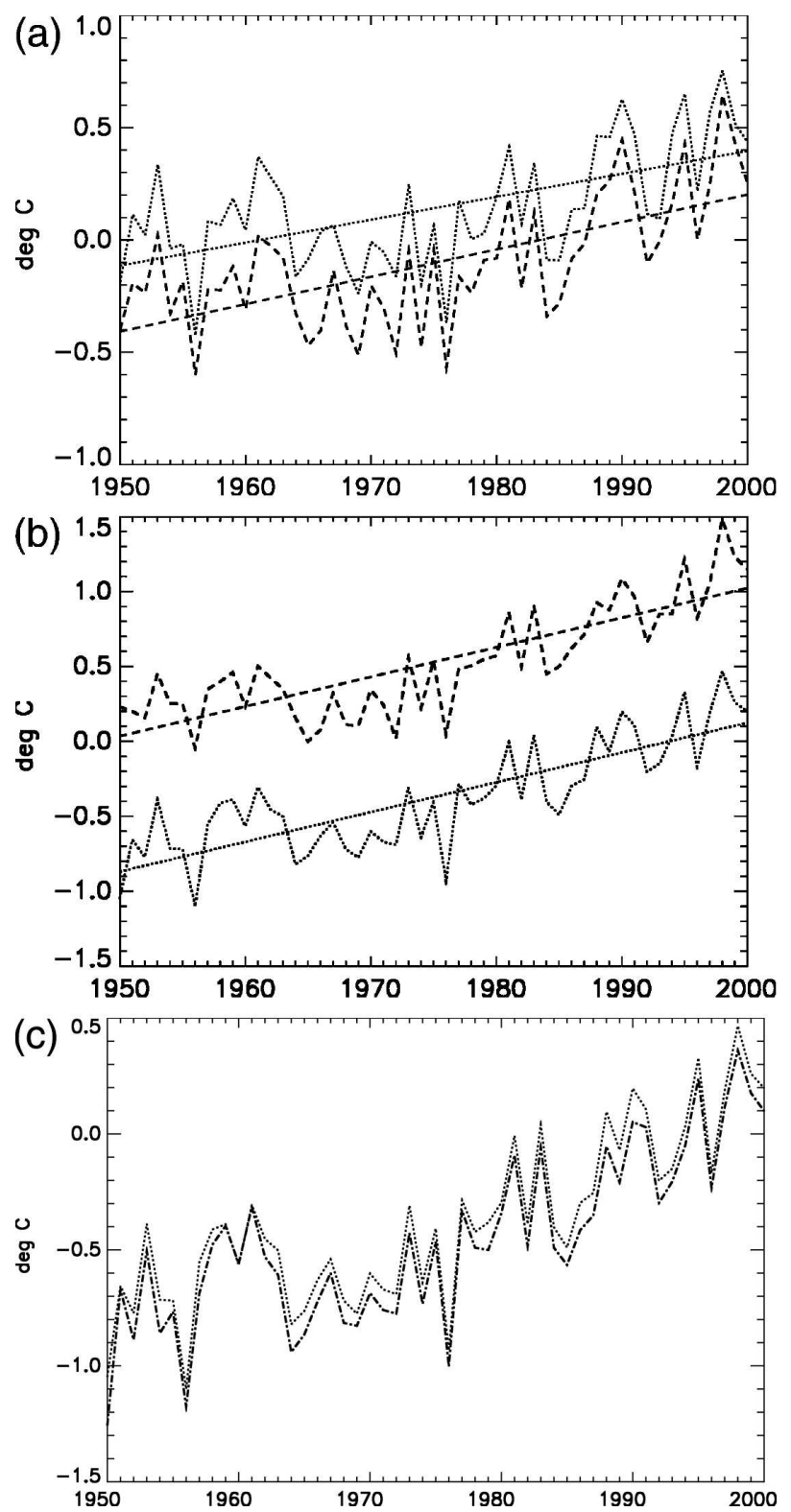

FIG. 4. (a) Annual global anomalies of $T_{\max }$ and (b) $T_{\min }$ on (dashed) windy and (dotted) calm days or nights. The linear trend fits, and the $\pm 2 \sigma$ error ranges given in the text were estimated by restricted maximum likelihood (Diggle et al. 1999), taking into account autocorrelation in the residuals. (c) Annual global anomalies of $T_{\min }$ on (dotted) calm (terce 1) nights and (dashdot) very calm (decile 1 ) nights.

$15^{\circ} \mathrm{W}-40^{\circ} \mathrm{E}$ ) in autumn and winter (Table 1). This resulted in an annual trend of $0.10^{\circ} \pm 0.04^{\circ} \mathrm{C}$ decade $^{-1}$ on windy nights relative to calm nights. There were also weak relative trends in the same sense in the Arctic $\left(>60^{\circ} \mathrm{N}\right)$ and Australasia $\left(10^{\circ} \mathrm{N}-60^{\circ} \mathrm{S}, 90^{\circ} \mathrm{E}-180^{\circ}\right.$; Table $1)$, and in the contiguous United States $\left(0.02^{\circ} \pm 0.05^{\circ} \mathrm{C}\right.$ decade $^{-1}$ on an annual basis), supporting the reported 
TABLE 1 . Trends in average $T_{\min },{ }^{\circ} \mathrm{C}$ decade ${ }^{-1}, 1950-2000$. The linear trend fits and the $\pm 2 \sigma$ error ranges were estimated by restricted maximum likelihood (Diggle et al. 1999), taking into account autocorrelation in the residuals. Trends for "windy minus calm" and "windy minus all" are only given where significant: $5 \%$ (italic) or 1\% (bold).

\begin{tabular}{|c|c|c|c|c|c|c|}
\hline Region & Season & All $(2 \sigma)$ & Windy $(2 \sigma)$ & Calm $(2 \sigma)$ & $\begin{array}{c}\text { Windy } \\
\text { minus calm }\end{array}$ & $\begin{array}{l}\text { Windy } \\
\text { minus all }\end{array}$ \\
\hline Globe & Year & $0.20(0.06)$ & $0.20(0.06)$ & $0.20(0.05)$ & & \\
\hline $\operatorname{Arctic}\left(60^{\circ}-90^{\circ} \mathrm{N}\right)$ & Year & $0.25(0.09)$ & $0.27(0.09)$ & $0.22(0.09)$ & 0.05 & \\
\hline \multirow[t]{5}{*}{ Europe $\left(35^{\circ}-70^{\circ} \mathrm{N}, 15^{\circ} \mathrm{W}-40^{\circ} \mathrm{E}\right)$} & Year & $0.17(0.14)$ & $0.22(0.13)$ & $0.13(0.14)$ & 0.10 & 0.06 \\
\hline & Dec-Feb & $0.27(0.27)$ & $0.37(0.23)$ & $0.21(0.28)$ & 0.19 & 0.11 \\
\hline & Mar-May & $0.17(0.14)$ & $0.17(0.13)$ & $0.17(0.14)$ & & \\
\hline & Jun-Aug & $0.12(0.10)$ & $0.14(0.12)$ & $0.10(0.10)$ & & \\
\hline & Sep-Nov & $0.08(0.14)$ & $0.16(0.16)$ & $0.03(0.14)$ & 0.13 & 0.08 \\
\hline \multirow[t]{5}{*}{ North America $\left(20^{\circ}-90^{\circ} \mathrm{N}, 50^{\circ} \mathrm{W}-180^{\circ}\right)$} & Year & $0.25(0.13)$ & $0.24(0.12)$ & $0.23(0.13)$ & & \\
\hline & Dec-Feb & $0.28(0.24)$ & $0.25(0.23)$ & $0.26(0.23)$ & & \\
\hline & Mar-May & $0.35(0.17)$ & $0.33(0.16)$ & $0.33(0.18)$ & & \\
\hline & Jun-Aug & $0.20(0.07)$ & $0.19(0.06)$ & $0.19(0.08)$ & & \\
\hline & Sep-Nov & $0.15(0.10)$ & $0.15(0.12)$ & $0.13(0.10)$ & & \\
\hline \multirow[t]{5}{*}{ Asia $\left(20^{\circ}-90^{\circ} \mathrm{N}, 40^{\circ} \mathrm{E}-180^{\circ}\right)$} & Year & $0.30(0.07)$ & $0.32(0.07)$ & $0.28(0.07)$ & & \\
\hline & Dec-Feb & $0.49(0.15)$ & $0.55(0.17)$ & $0.44(0.15)$ & 0.10 & \\
\hline & Mar-May & $0.34(0.12)$ & $0.33(0.11)$ & $0.33(0.12)$ & & \\
\hline & Jun-Aug & $0.14(0.07)$ & $0.16(0.05)$ & $0.15(0.06)$ & & 0.02 \\
\hline & Sep-Nov & $0.23(0.08)$ & $0.25(0.10)$ & $0.22(0.09)$ & & \\
\hline \multirow[t]{3}{*}{$\mathrm{NH}$ north of $20^{\circ} \mathrm{N}$} & Year & $0.24(0.08)$ & $0.26(0.08)$ & $0.21(0.08)$ & 0.04 & 0.02 \\
\hline & Dec-Feb & $0.34(0.14)$ & $0.38(0.14)$ & $0.30(0.13)$ & 0.09 & 0.04 \\
\hline & Jun-Aug & $0.16(0.08)$ & $0.17(0.08)$ & $0.16(0.07)$ & & \\
\hline & Year & $0.18(0.04)$ & $0.17(0.03)$ & $0.18(0.05)$ & & \\
\hline \multirow{5}{*}{ Australasia $\left(10^{\circ}-60^{\circ} \mathrm{S}, 90^{\circ} \mathrm{E}-180^{\circ}\right)$} & Year & $0.11(0.04)$ & $0.12(0.05)$ & $0.10(0.04)$ & 0.02 & 0.01 \\
\hline & Dec-Feb & $0.13(0.06)$ & $0.13(0.05)$ & $0.11(0.05)$ & & \\
\hline & Mar-May & $0.09(0.06)$ & $0.12(0.06)$ & $0.06(0.07)$ & 0.05 & 0.03 \\
\hline & Jun-Aug & $0.09(0.07)$ & $0.09(0.08)$ & $0.08(0.07)$ & & \\
\hline & Sep-Nov & $0.13(0.05)$ & $0.15(0.06)$ & $0.11(0.05)$ & 0.04 & 0.02 \\
\hline
\end{tabular}

lack of urban warming there (Peterson 2003; Peterson and Owen 2005). Conversely, in the Tropics $\left(20^{\circ} \mathrm{N}-\right.$ $20^{\circ} \mathrm{S}$ ), windy nights cooled (though insignificantly) relative to calm nights on an annual average (Table 1 and Fig. 5). The European trends in winter are explained below in terms of atmospheric circulation changes. In the extratropical Northern Hemisphere north of $20^{\circ} \mathrm{N}$

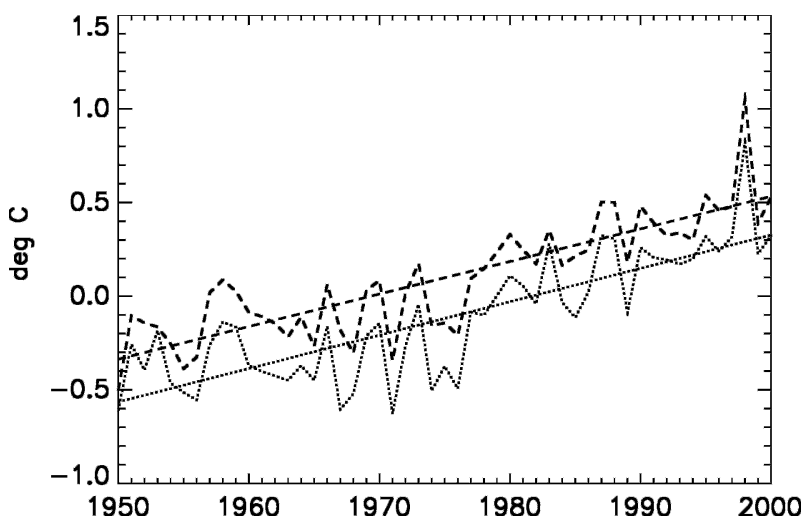

FIG. 5. Same as in Fig. 4a, but for tropical $\left(20^{\circ} \mathrm{N}-20^{\circ} \mathrm{S}\right)$ anomalies of $T_{\min }$ on (dashed) windy and (dotted) calm nights.
(NH20; Fig. 6c,d and Table 1), there was no significant change of $T_{\min }$ on windy nights relative to calm nights in summer, when atmospheric circulation changes are less influential. Any urban warming signal should be most evident in summer, when urban heat islands are stronger owing to greater storage of solar heat in urban structures.

For 1950-2000, the linear trends of global annual average $T_{\max }$ were $0.13^{\circ} \pm 0.05^{\circ} \mathrm{C}\left(0.10^{\circ} \pm 0.06^{\circ} \mathrm{C}\right)$ decade $^{-1}$ for windy (calm) conditions and $0.12^{\circ} \pm 0.05^{\circ} \mathrm{C}$ decade $^{-1}$ for all data. The difference between the windy-day trend and the calm-day trend is reflected in Fig. 4a. The annual trends of $T_{\max }$ for windy minus calm are positive - not an urbanization signal-and statistically significant for the globe, NH20, the Arctic, Europe, Asia $\left(20^{\circ}-90^{\circ} \mathrm{N}, 40^{\circ} \mathrm{E}-180^{\circ}\right)$, and North America $\left(20^{\circ}-90^{\circ} \mathrm{N}, 50^{\circ} \mathrm{W}-180^{\circ}\right)$, but not for the Tropics or Australasia (Table 2). As with $T_{\min }$, the relative trends mainly arose from the winter season and to a lesser extent autumn in Eurasia (Table 2). For NH20 (Fig. 6a,b), $T_{\max }$ warmed by $0.29^{\circ} \pm 0.11^{\circ} \mathrm{C}\left(0.15^{\circ} \pm 0.13^{\circ} \mathrm{C}\right)$ decade $^{-1}$ for windy (calm) conditions in winter but by $0.07^{\circ} \pm 0.08^{\circ} \mathrm{C}\left(0.08^{\circ} \pm 0.07^{\circ} \mathrm{C}\right) \mathrm{decade}^{-1}$ for windy 

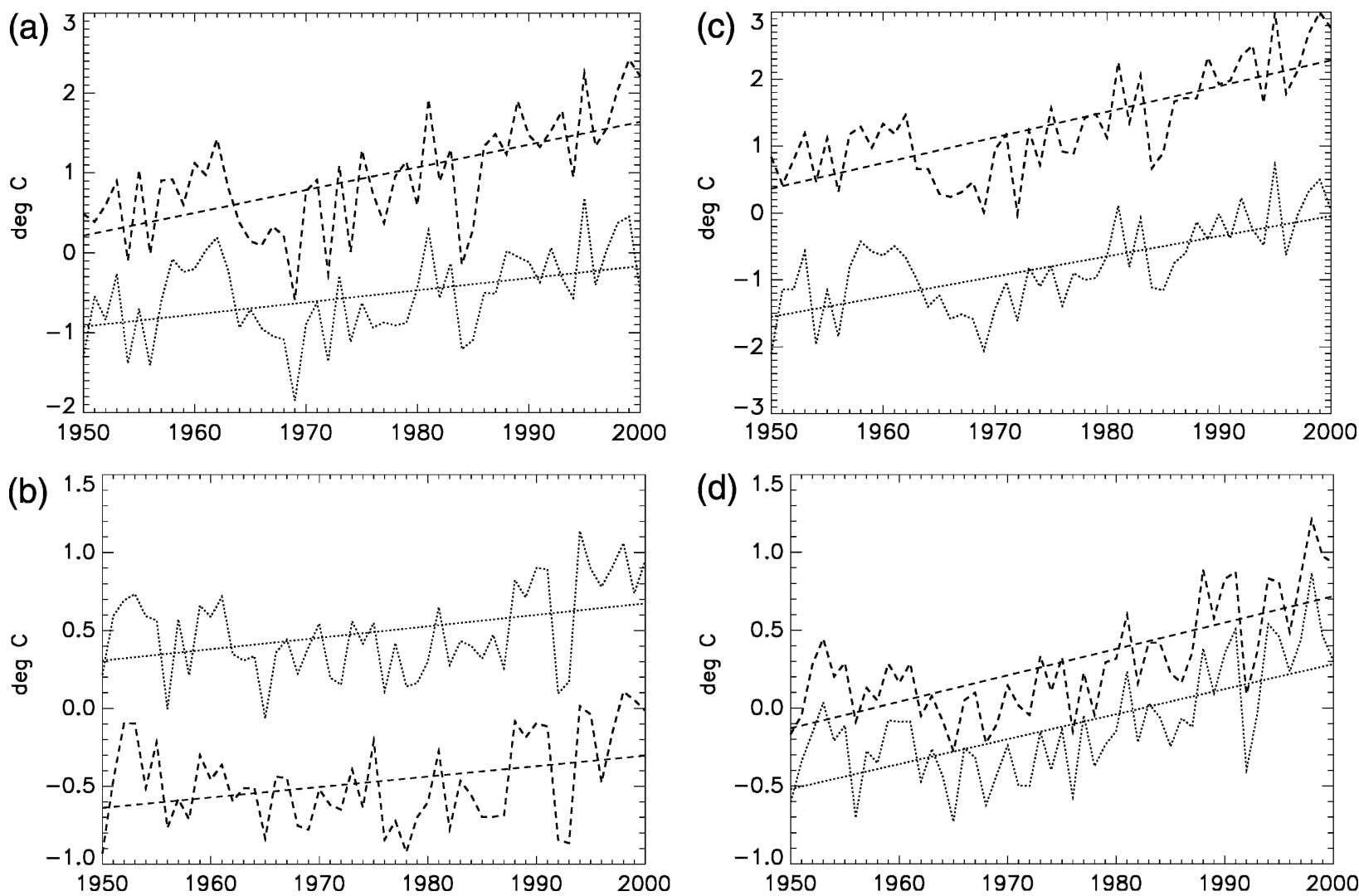

FIG. 6. (a) Anomalies of $T_{\max }$ for winter (December-February) and (b) summer (June-August) in the NH north of $20^{\circ} \mathrm{N}$ on (dashed) windy and (dotted) calm days. The linear trend fits and the $\pm 2 \sigma$ error ranges given in the text were estimated by restricted maximum likelihood (Diggle et al. 1999), taking into account autocorrelation in the residuals. $T_{\max }$ is, as expected, lower on windy than on calm days in summer (b), but higher on windy than on calm days in winter (a), because persistent near-surface inversions are limited to calm weather. (c), (d) Same as in (a), (b), but for $T_{\min } . T_{\min }$ is, as expected, higher on windy than on calm nights in both winter and summer.

(calm) conditions in summer. An influence of atmospheric circulation changes in winter is suggested. The observed tendency of an increased positive phase of the North Atlantic Oscillation (Folland et al. 2001b) implies that the windier days in western Eurasia tended toward increased warm advection from the west or southwest (Hurrell and van Loon 1997), yielding greater warming in windy conditions. This finding implies that the comparison of trends of $T_{\max }$ or $T_{\min }$ between windy and calm conditions may not always be able to detect small urban warming trends at individual stations or on subcontinental scales in winter in middle and high latitudes. However, in other seasons and on hemispheric and global scales, atmospheric circulation effects are likely to be small and/or cancelled out, allowing any urban warming signal to be detected.

The observed decline in diurnal temperature range $T_{\text {range }}$ (Folland et al. 2001b; Easterling et al. 1997) is insignificantly weakened (from $-0.08^{\circ}$ to $-0.07^{\circ} \pm$ $0.02^{\circ} \mathrm{C}$ decade $^{-1}$ ) by subsampling on windy days (Table
3). The overall decline of $T_{\text {range }}$ is significant and consistent with reported increases in cloudiness (Folland et al. 2001b; Dai et al. 1997).

\section{Additional comparisons}

Because a small (though widespread) sample was used, the robustness of the results was tested by comparing global trends for 1950-93 with published allconditions trends based on a much larger sample (Easterling et al. 1997). For that period, the global annual trends of $T_{\min }$ in the present study were $0.16^{\circ} \pm 0.07^{\circ} \mathrm{C}$ decade $^{-1}$ for all conditions and $0.16^{\circ} \pm 0.07^{\circ} \mathrm{C}\left(0.17^{\circ} \pm\right.$ $0.07^{\circ} \mathrm{C}$ ) decade ${ }^{-1}$ for windy (calm) conditions. Global annual trends of $T_{\max }$ for $1950-93$ were $0.08^{\circ} \pm 0.06^{\circ} \mathrm{C}$ decade $^{-1}$ (full sample) and $0.09^{\circ} \pm 0.06^{\circ} \mathrm{C}\left(0.06^{\circ} \pm\right.$ $0.07^{\circ} \mathrm{C}$ ) decade ${ }^{-1}$ for windy (calm) conditions. These are close to the annual average of the seasonal global all-conditions trends for $>5000$ nonurban stations for 1950-93 (Easterling et al. 1997): $0.17^{\circ} \mathrm{C}$ decade $^{-1}$ for 
TABle 2. Same as in Table 1, but for $T_{\max }$.

\begin{tabular}{|c|c|c|c|c|c|c|}
\hline Region & Season & All $(2 \sigma)$ & Windy $(2 \sigma)$ & Calm $(2 \sigma)$ & $\begin{array}{c}\text { Windy } \\
\text { minus calm }\end{array}$ & $\begin{array}{l}\text { Windy } \\
\text { minus all }\end{array}$ \\
\hline Globe & Year & $0.12(0.05)$ & $0.13(0.05)$ & $0.10(0.06)$ & 0.02 & \\
\hline $\operatorname{Arctic}\left(60^{\circ}-90^{\circ} \mathrm{N}\right)$ & Year & $0.15(0.09)$ & $0.17(0.09)$ & $0.11(0.09)$ & 0.07 & 0.03 \\
\hline \multirow{5}{*}{ Europe $\left(35^{\circ}-70^{\circ} \mathrm{N}, 15^{\circ} \mathrm{W}-40^{\circ} \mathrm{E}\right)$} & Year & $0.11(0.12)$ & $0.17(0.11)$ & $0.06(0.13)$ & 0.11 & 0.06 \\
\hline & Dec-Feb & $0.25(0.25)$ & $0.36(0.18)$ & $0.14(0.25)$ & 0.24 & 0.12 \\
\hline & Mar-May & $0.12(0.16)$ & $0.12(0.15)$ & $0.07(0.17)$ & & \\
\hline & Jun-Aug & $0.05(0.09)$ & $0.05(0.12)$ & $0.02(0.09)$ & & \\
\hline & Sep-Nov & $0.03(0.10)$ & $0.08(0.13)$ & $-0.01(0.10)$ & 0.09 & 0.05 \\
\hline \multirow[t]{5}{*}{ North America $\left(20^{\circ}-90^{\circ} \mathrm{N}, 50^{\circ} \mathrm{W}-180^{\circ}\right)$} & Year & $0.15(0.11)$ & $0.18(0.10)$ & $0.13(0.12)$ & 0.05 & 0.03 \\
\hline & Dec-Feb & $0.18(0.19)$ & $0.19(0.18)$ & $0.16(0.19)$ & & \\
\hline & Mar-May & $0.27(0.14)$ & $0.31(0.15)$ & $0.23(0.17)$ & & \\
\hline & Jun-Aug & $0.12(0.06)$ & $0.11(0.07)$ & $0.12(0.07)$ & & \\
\hline & Sep-Nov & $0.02(0.13)$ & $0.06(0.10)$ & $-0.02(0.15)$ & 0.09 & 0.05 \\
\hline \multirow[t]{5}{*}{ Asia $\left(20^{\circ}-90^{\circ} \mathrm{N}, 40^{\circ} \mathrm{E}-180^{\circ}\right)$} & Year & $0.17(0.08)$ & $0.19(0.08)$ & $0.13(0.08)$ & 0.06 & \\
\hline & Dec-Feb & $0.32(0.17)$ & $0.37(0.18)$ & $0.21(0.16)$ & 0.16 & \\
\hline & Mar-May & $0.22(0.12)$ & $0.21(0.12)$ & $0.20(0.12)$ & & \\
\hline & Jun-Aug & $0.07(0.08)$ & $0.04(0.09)$ & $0.06(0.07)$ & & -0.03 \\
\hline & Sep-Nov & $0.11(0.11)$ & $0.13(0.10)$ & $0.08(0.10)$ & & \\
\hline \multirow[t]{3}{*}{$\mathrm{NH}$ north of $20^{\circ} \mathrm{N}$} & Year & $0.14(0.08)$ & $0.17(0.08)$ & $0.10(0.08)$ & 0.07 & 0.02 \\
\hline & Dec-Feb & $0.24(0.13)$ & $0.29(0.11)$ & $0.15(0.13)$ & 0.14 & 0.05 \\
\hline & Jun-Aug & $0.09(0.07)$ & $0.07(0.08)$ & $0.08(0.07)$ & & -0.02 \\
\hline Tropics $\left(20^{\circ} \mathrm{N}-20^{\circ} \mathrm{S}\right)$ & Year & $0.08(0.05)$ & $0.08(0.05)$ & $0.07(0.05)$ & & \\
\hline \multirow{5}{*}{ Australasia $\left(10^{\circ}-60^{\circ} \mathrm{S}, 90^{\circ} \mathrm{E}-180^{\circ}\right)$} & Year & $0.10(0.04)$ & $0.11(0.05)$ & $0.10(0.04)$ & & \\
\hline & Dec-Feb & $0.10(0.05)$ & $0.08(0.08)$ & $0.11(0.06)$ & & \\
\hline & Mar-May & $0.09(0.05)$ & $0.11(0.06)$ & $0.07(0.06)$ & & \\
\hline & Jun-Aug & $0.12(0.06)$ & $0.12(0.07)$ & $0.12(0.07)$ & & \\
\hline & Sep-Nov & $0.10(0.07)$ & $0.14(0.08)$ & $0.06(0.07)$ & 0.08 & 0.04 \\
\hline
\end{tabular}

TABLE 3. Same as in Table 1, but for the diurnal temperature range.

\begin{tabular}{|c|c|c|c|c|c|c|}
\hline Region & Season & All $(2 \sigma)$ & Windy $(2 \sigma)$ & Calm $(2 \sigma)$ & $\begin{array}{l}\text { Windy } \\
\text { minus calm }\end{array}$ & $\begin{array}{l}\text { Windy } \\
\text { minus all }\end{array}$ \\
\hline Globe & Year & $-0.08(0.02)$ & $-0.07(0.02)$ & $-0.10(0.02)$ & 0.02 & \\
\hline $\operatorname{Arctic}\left(60^{\circ}-90^{\circ} \mathrm{N}\right)$ & Year & $-0.11(0.03)$ & $-0.09(0.04)$ & $-0.11(0.02)$ & & 0.01 \\
\hline \multirow[t]{5}{*}{ Europe $\left(35^{\circ}-70^{\circ} \mathrm{N}, 15^{\circ} \mathrm{W}-40^{\circ} \mathrm{E}\right)$} & Year & $-0.05(0.03)$ & $-0.05(0.03)$ & $-0.06(0.03)$ & & \\
\hline & Dec-Feb & $-0.01(0.04)$ & $0.00(0.04)$ & $-0.06(0.06)$ & 0.06 & \\
\hline & Mar-May & $-0.05(0.05)$ & $-0.05(0.05)$ & $-0.10(0.07)$ & & \\
\hline & Jun-Aug & $-0.07(0.05)$ & $-0.09(0.05)$ & $-0.08(0.05)$ & & \\
\hline & Sep-Nov & $-0.04(0.05)$ & $-0.07(0.05)$ & $-0.03(0.05)$ & & -0.04 \\
\hline \multirow[t]{5}{*}{ North America $\left(20^{\circ}-90^{\circ} \mathrm{N}, 50^{\circ} \mathrm{W}-180^{\circ}\right)$} & Year & $-0.10(0.08)$ & $-0.06(0.07)$ & $-0.11(0.07)$ & 0.04 & 0.03 \\
\hline & Dec-Feb & $-0.10(0.09)$ & $-0.05(0.09)$ & $-0.09(0.07)$ & & 0.04 \\
\hline & Mar-May & $-0.08(0.09)$ & $-0.02(0.08)$ & $-0.11(0.09)$ & 0.08 & 0.05 \\
\hline & Jun-Aug & $-0.07(0.04)$ & $-0.08(0.03)$ & $-0.07(0.03)$ & & \\
\hline & Sep-Nov & $-0.14(0.08)$ & $-0.09(0.10)$ & $-0.16(0.09)$ & & 0.05 \\
\hline \multirow[t]{5}{*}{ Asia $\left(20^{\circ}-90^{\circ} \mathrm{N}, 40^{\circ} \mathrm{E}-180^{\circ}\right)$} & Year & $-0.12(0.03)$ & $-0.13(0.03)$ & $-0.15(0.04)$ & & \\
\hline & Dec-Feb & $-0.17(0.07)$ & $-0.17(0.06)$ & $-0.24(0.08)$ & 0.06 & 0.03 \\
\hline & Mar-May & $-0.12(0.03)$ & $-0.12(0.04)$ & $-0.14(0.04)$ & & \\
\hline & Jun-Aug & $-0.08(0.03)$ & $-0.13(0.03)$ & $-0.09(0.03)$ & & -0.05 \\
\hline & Sep-Nov & $-0.13(0.05)$ & $-0.12(0.05)$ & $-0.14(0.06)$ & & \\
\hline \multirow[t]{3}{*}{$\mathrm{NH}$ north of $20^{\circ} \mathrm{N}$} & Year & $-0.09(0.03)$ & $-0.08(0.05)$ & $-0.12(0.03)$ & 0.03 & \\
\hline & Dec-Feb & $-0.10(0.04)$ & $-0.09(0.04)$ & $-0.15(0.05)$ & 0.05 & \\
\hline & Jun-Aug & $-0.08(0.03)$ & $-0.10(0.03)$ & $-0.09(0.02)$ & & \\
\hline Tropics $\left(20^{\circ} \mathrm{N}-20^{\circ} \mathrm{S}\right)$ & Year & $-0.09(0.01)$ & $-0.09(0.03)$ & $-0.10(0.02)$ & & \\
\hline \multirow[t]{5}{*}{ Australasia $\left(10^{\circ}-60^{\circ} \mathrm{S}, 90^{\circ} \mathrm{E}-180^{\circ}\right)$} & Year & $-0.01(0.04)$ & $-0.01(0.04)$ & $-0.00(0.04)$ & & \\
\hline & Dec-Feb & $-0.03(0.04)$ & $-0.05(0.06)$ & $-0.01(0.05)$ & -0.05 & \\
\hline & Mar-May & $0.01(0.07)$ & $-0.01(0.07)$ & $0.01(0.07)$ & & \\
\hline & Jun-Aug & $0.03(0.07)$ & $0.03(0.07)$ & $0.05(0.07)$ & & \\
\hline & Sep-Nov & $-0.03(0.06)$ & $-0.02(0.06)$ & $-0.05(0.07)$ & & \\
\hline
\end{tabular}




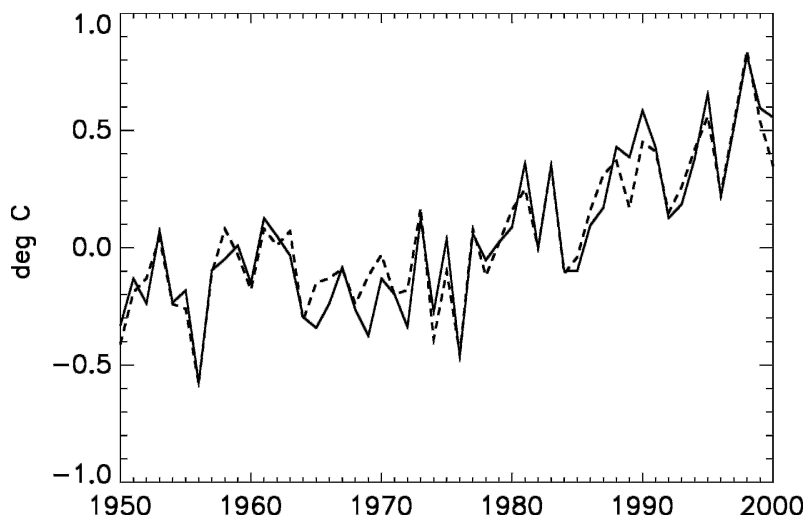

FIG. 7. Annual global anomalies of $T_{\text {mean }}$ from the (solid) stations used in this analysis and from the (dashed) Jones and Moberg (2003) dataset.

$T_{\min }$ and $0.07^{\circ} \mathrm{C}$ decade ${ }^{-1}$ for $T_{\text {max }}$. The trend in global mean temperature in 1950-2000 in the sample used in the present study, $0.16^{\circ} \pm 0.05^{\circ} \mathrm{C}$, is also not significantly different from that in the full Jones and Moberg (2003) dataset, $0.15^{\circ} \pm 0.05^{\circ} \mathrm{C}$ (Fig. 7). The robustness of the small sample (up to 270 stations) arises because the spatial coherence of surface temperature variations and trends yields only about 20 spatial degrees of freedom for annual averages, and fewer on decadal time scales (Jones et al. 1997). The interannual variability of global temperature anomalies in the sample used in this study slightly exceeds that in Jones and Moberg (2003; Fig. 7) because of its sparser coverage and greater relative concentration of stations over the Northern Hemisphere continents.

\section{Conclusions}

The analysis would have benefited from more daily data over Africa and South America (Mason et al. 2003; Fig. 1 of this paper). A future increase in daily data availability may be expected through the GCOS Implementation Plan (GCOS 2004). For detailed urban warming studies, however, higher-resolution (e.g., hourly) data will be required.

Nevertheless, the network of stations used in this study has been shown to be adequate for the representation of large-scale air temperature trends over land. The analysis of $T_{\min }$ demonstrates that neither urbanization nor other local instrumental or thermal effects have systematically exaggerated the observed global warming trends in $T_{\min }$. The robustness of the analysis to the criterion for "calm" implies that the estimated overall trends are insensitive to boundary layer structure and small-scale advection, and to siting, instrumentation, and observing practices that increasingly influ- ence temperatures as winds become lighter. Furthermore, even at windy sites (e.g., St. Paul, Aleutian Islands, in Fig. C1), the calmest terce and especially the calmest decile will be strongly affected by occasions with very light winds in passing ridges or blocking anticyclones, and should reveal any urban warming influence.

The analysis of $T_{\max }$ supports the findings for $T_{\min }$ while also showing the influence of regional atmospheric circulation changes.

In view of the error estimates (Tables 1 and 2) and the different periods of analysis, the results are compatible with the IPCC TAR conclusion that urban warming is responsible for an uncertainty of $0.06^{\circ} \mathrm{C}$ in the global warming in the twentieth century. Nevertheless, the reality of global-scale warming is strongly supported by the overall near equality of temperature trends on windy days with trends based on all data.

The reality of urban warming on local (Arnfield 2003; Johnson et al. 1991) and small regional scales (e.g., Zhou et al. 2004) is not questioned by this work; it is the impact of urban warming on estimates of global and large regional trends that is shown to be small.

Because changes of siting, instrumentation, or observing practice are likely to have the greatest impact in calm, cloudless weather, analyses of individual station temperature data in such conditions could be used to supplement or validate station metadata. In turn, improved metadata will allow refined estimates of climatic changes, especially on local and small regional scales. When data are averaged over hemispheres and the globe, these types of heterogeneity are likely to cancel out to some extent, and the results of the present study also suggest that they have not affected the estimates of temperature trends.

Acknowledgments. Data were provided by J. Cappelen (Danish Meteorological Institute), D. Kiktev (Russian Hydrometeorological Institute), R. Ray (National Climatic Data Center), M. J. Salinger [NIWA New Zealand: Asia-Pacific network (APN) data], L. Vincent (Environment Canada), and P. Zhai (China Meteorological Administration). C. K. Folland provided useful comments. This work was supported by the U.K. Government Research Program and this paper is U.K. Crown Copyright.

\section{APPENDIX A}

\section{National Practices for Ascribing Dates to Maximum Temperatures}

When a 24-h maximum temperature is read in the morning, some countries record it against the date of 
reading the instrument whereas others record it against the previous day when, it is presumed, the maximum temperature usually occurred. A further complication arises where the local date differs from the UTC date. For example, between $135^{\circ} \mathrm{E}$ and the date line, at 0900 local time (often adopted as the time for reading instruments), the previous day is still current at the Greenwich meridian on which UTC is based. Listed below are national conventions for recording maximum temperature. This information was used to align the maximum temperatures with the appropriate daily mean wind strength from the NCEP-NCAR reanalysis (Kalnay et al. 1996).

The following information was provided by national contacts.

Australia: Maxima and minima are ascribed to the local date of occurrence in Western Australia, the Indian Ocean Islands, and Antarctica but to the previous date in central and eastern states (P. Della Marta 2002, personal communication).

China: Maxima are ascribed to the local day of occurrence (P. Zhai 2002, personal communication).

Denmark and Greenland: The maxima are ascribed to the following date, when the instruments are read (J. Cappelen 2002, personal communication). The same is implied by Laursen (2002).

New Zealand and the southwest Pacific islands (APN dataset): Maxima are ascribed to the local date of occurrence.

New Zealand and its southwest Pacific islands (not APN dataset): Data are ascribed to the New Zealand local date at the time of observation (A. Harper 2003, personal communication). For example, Campbell Island $\left(169^{\circ} \mathrm{E}\right) T_{\max }$ and $T_{\min }$ ascribed to 23 May refer to the 24-h period from 0900 on 22 May to 0900 on 23 May, New Zealand Time, so both should be matched with winds for 22 May in UTC time. An irregularity is that the Pitcairn Island (across the date line at $\left.130^{\circ} \mathrm{W}\right) T_{\text {max }}$ ascribed to 23 May refers to the 24-h period from 0600 on 22 May to 0600 on 23 May, New Zealand Time (from 0900 on 21 May to 0900 on 22 May, Pitcairn Island Time), so $T_{\max }$ and $T_{\min }$ should also be matched with winds for 22 May in UTC time.

United Kingdom: Maxima are ascribed to the date of occurrence.

United States: The policy is that observations are recorded as if they were made when the thermometers were read. Some observers, however, ascribe the observations to the day before. Whenever this practice is detected, the data are reassigned to the date on which the observations were made
(T. Peterson 2002, personal communication). Thus, $T_{\max }$ is, in theory, ascribed to the date after it occurs. An analysis (by the author of this paper) of average maximum temperature anomalies on calm versus windy days, with and without a 1-day offset, suggested that $T_{\max }$ occurred on the day before the ascribed date as implied by the policy, except at San Juan, Majuro, and Koror. At these three stations, $T_{\max }$ occurred on the ascribed date. Their data were analyzed accordingly.

The following was deduced from published books of data.

Japan, Philippines, South Korea, and Thailand: Maxima are ascribed to the local date of occurrence.

The following was deduced from samples of plotted data on Met Office or NOAA daily weather reports:

Canada, the former Soviet Union, and Ireland: Maxima are ascribed to the local date of occurrence.

The following was deduced from mean sea level pressure patterns from the NCEP-NCAR reanalysis (Kalnay et al. 1996).

South Africa (Marion Island): Maxima are ascribed to the local date of occurrence.

The following was deduced from average maximum temperature anomalies on calm versus windy days, with and without a 1-day offset.

Algeria, Austria, France, Germany, Iceland, Ireland, Israel, Kuwait, Malaysia, Mauritius, Namibia, New Caledonia, Norway, Poland, Seychelles, Sweden, Switzerland, and Uruguay: Maxima are ascribed to the local date of occurrence.

Colombia, Papua New Guinea, Saudi Arabia, and Syria: The evidence is unclear; assume that maxima are ascribed to the local date of occurrence.

Greece and Mongolia: The maxima are ascribed to the following date.

\section{APPENDIX B}

\section{Stations Showing Urban Warming or Other Heterogeneities}

Of the 290 stations studied, only 13, listed in Table B1 with their World Meteorological Organization numbers, showed significant warming of calm relative to windy $T_{\min }$. However, comparison of calm with windy $T_{\text {min }}$ did not always detect the known slight urban 
TABLE B1. Stations showing significant warming of calm relative to windy $T_{\min }$.

\begin{tabular}{lll}
\hline 06700 Geneva-Cointrin* & 07650 Marseille & 40061 Palmyra \\
47112 Inchon & 59758 Haikou & 70261 Fairbanks \\
71082 Alert & 71924 Resolute & 71946 Fort Simpson \\
78526 San Juan & 91753 Hihifo & 91765 Pago Pago \\
98653 Surigao & & \\
\hline
\end{tabular}

warming influences at individual locations, for example, in central England temperature (Manley 1974; Parker et al. 1992), because, for instance, the source of the air on windy days may change systematically (see main text). Another 21 stations, listed in Table B2, showed other systematic discontinuities or trends of uncertain origin in calm relative to windy $T_{\max }$ or $T_{\min }$. Stations in Tables B1 and B2 marked with an asterisk were not used in the global and regional analyses because a station with a longer or more complete record shared the same $5^{\circ}$ grid box (see main text). In addition, Shanghai, although not sharing a $5^{\circ}$ grid box, was not used as it showed marked cooling on calm relative to windy days and nights, possibly indicating a site change.

A discontinuity at Fresno, California, is illustrated in Fig. B1. Because changes of siting, instrumentation, or observing practice are likely to have the greatest impact in calm, cloudless weather (see main text), analyses like Fig. B1 could be used, along with appropriate statistical tests, to supplement or validate station metadata.

\section{APPENDIX C}

\section{Comparisons between Station Nighttime Winds and NCEP-NCAR Reanalysis Daily Average Winds}

Station wind speeds for 26 locations in North America and Siberia (triangles in Fig. 1b) were compared with corresponding NCEP-NCAR reanalysis daily average winds. The station winds were selected to be for a constant nighttime hour as close to dawn as possible to coincide with the most usual time of $T_{\min }$.

TABLE B2. Stations showing other systematic discontinuities or trends in calm relative to windy $T_{\max }$ or $T_{\min }$.

\begin{tabular}{lll}
\hline \hline 04092 Teigarhorn & 17062 Istanbul & 17240 Isparta \\
23849 Surgut* & $\begin{array}{l}\text { 31369 Nikolaev-na- } \\
\text { Amur }\end{array}$ & 36177 Semipalatinsk* \\
& 44259 Choibal & 47165 Mokpo \\
44231 Muren & 48568 Songkhla & 50527 Hailar \\
48500 Prachuap & 54342 Shenyang & 56294 Chengdu \\
52203 Hami & 71090 Clyde & 72389 Fresno \\
58362 Shanghai & 91376 Majuro & 91592 Noumea \\
91348 Ponape &
\end{tabular}

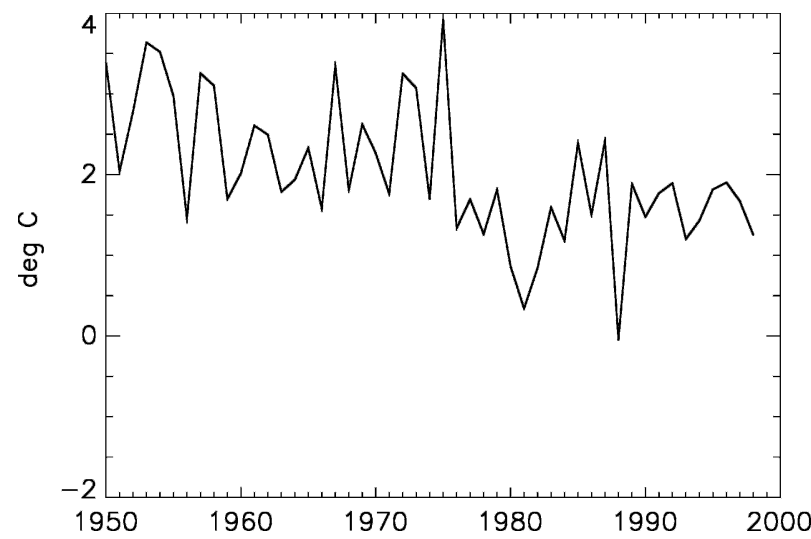

FIG. B1. Annually averaged $T_{\max }\left({ }^{\circ} \mathrm{C}\right.$, relative to 1961-90) at Fresno, CA, on calm relative to windy days. The discontinuity in the mid-1970s is not evident in the corresponding analysis of $T_{\text {min }}$ (not shown).

For 18 of the stations, correlations were in the range 0.6-0.8; the least well correlated station, Phoenix (Arizona), scored 0.2-0.5. At the 14 Russian stations, the ratio (station wind speed/reanalysis wind speed) averaged $17 \%$ less in the period $1979-2000$ than previously, when the reanalysis lacked satellite data. For the 12 North American stations, this ratio fell by $5 \%$. Nonetheless, scatterplots show that both before and after 1979, an NCEP-NCAR reanalysis daily average wind in terce 1 represented an enhanced likelihood of very light wind being observed at the station, even at poorly correlated Phoenix (Fig. C1). The ratio of NCEPNCAR reanalysis wind speed at the upper limit of terce 1 to that at the upper limit of decile 1 is typically nearly 2 at the 26 stations. At eight tropical stations representing a wide range of longitudes, this ratio is also typically nearly 2 , except during seasons of persistent maritime trade winds at three of these stations, when it is 1.251.5. Now the systematic global offset between very calm (decile 1) and calm (terce 1) $T_{\min }$ is less than $0.1^{\circ} \mathrm{C}$ (Fig. 4c). So the small fractional changes in station wind speed relative to NCEP-NCAR reanalysis wind speed are unlikely to have caused a global bias in trends of $T_{\min }$ in calm conditions approaching $-0.1^{\circ} \mathrm{C}$ over this 50 -yr period, that is, $-0.02^{\circ} \mathrm{C}$ decade $^{-1}$ or one-tenth of the magnitude of the observed warming signal.

\section{APPENDIX D}

\section{Analysis Using Proxy Low-Level Cloudiness}

A selection of 25 stations (locations with squares in Fig. 1b) was used in a comparison of $T_{\min }$ on dates with low (bottom terce, assumed to represent clear conditions) and high (top terce, assumed to represent cloudy 

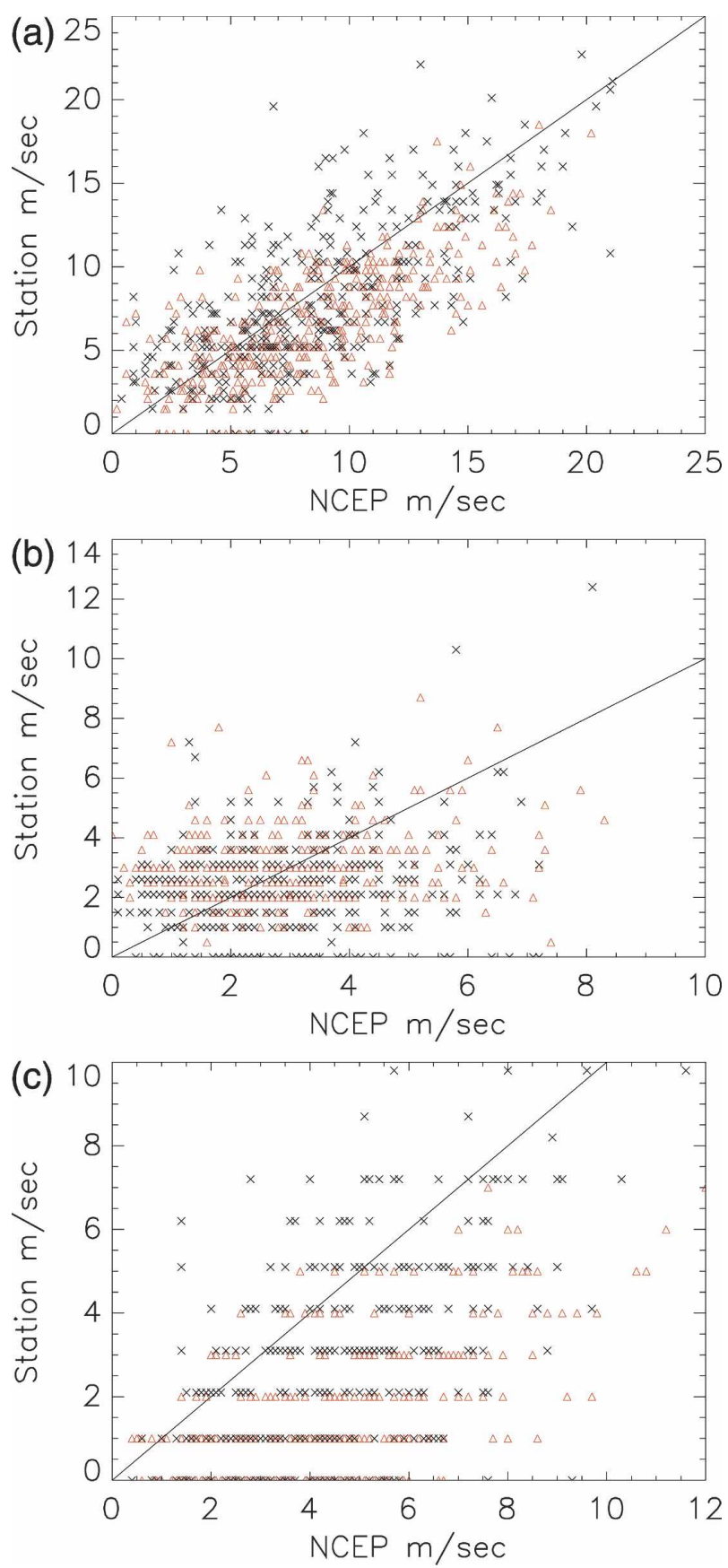

FIG. C1. Comparison of NCEP-NCAR reanalysis near-surface and station winds at St. Paul (Aleutian Islands), Phoenix (AZ), and Vytegra (Russia). The plotted lines represent the equality of wind speeds.

conditions) daily average relative humidity at $850 \mathrm{hPa}$ $\left(\mathrm{RH}_{850}\right)$ in the NCEP-NCAR reanalysis (Kalnay et al. 1996). The 850-hPa level was selected because low-level clouds, being warmer in general, have a greater influence than higher-level clouds on nighttime surface temperatures. The detection of colder nights by this proxy for clear skies was often, but not always, stronger than the detection of colder nights by light winds. There was no systematic tendency for clear nights to warm relative to cloudy nights, which would be a symptom of urban warming. However, at about a quarter of the stations, the time series of station $T_{\text {min }}$ for clear minus cloudy nights showed discontinuities, mainly but not exclusively before 1975, which were not evident in the analysis with respect to the NCEP-NCAR reanalysis surface winds. These discontinuities may have arisen from heterogeneities in the reanalysis resulting from changes in radiosonde humidity data availability, instrumentation, or processing techniques (Elliott and Gaffen 1991; Elliott et al. 1998). Figure D1 is an example for a Siberian station. The analysis failed to detect the known urban warming at Fairbanks, Alaska (Magee et al. 1999), whereas the analysis using near-surface winds did so (cf. Fig. D2 with Fig. 2), and the relative change of $T_{\min }$ appeared as a discontinuity in the late 1960s.

At 15 of the stations, sufficient cloud cover observations, made visually from ground level at the same nighttime hour as the wind observations used in appendix $\mathrm{C}$, were available to allow comparisons with the daily average NCEP-NCAR reanalysis $\mathrm{RH}_{850}$. Where available, the coverage of the lowest main cloud deck (SYNOP code $N_{h}$ ) was selected, otherwise the total cloud cover $N$ was used. Correlations were typically $0.5-0.7$, but $0.2-0.3$ in some seasons at one-third of the stations. Although there was a tendency for $\mathrm{RH}_{850}$ to decline relative to observed cloud cover, there was no clear relationship between changes or discontinuities in $\mathrm{RH}_{850} / N_{h}$ and changes or discontinuities in $T_{\text {min }}$ on low $\mathrm{RH}_{850}$ nights relative to high $\mathrm{RH}_{850}$ nights. The ob-

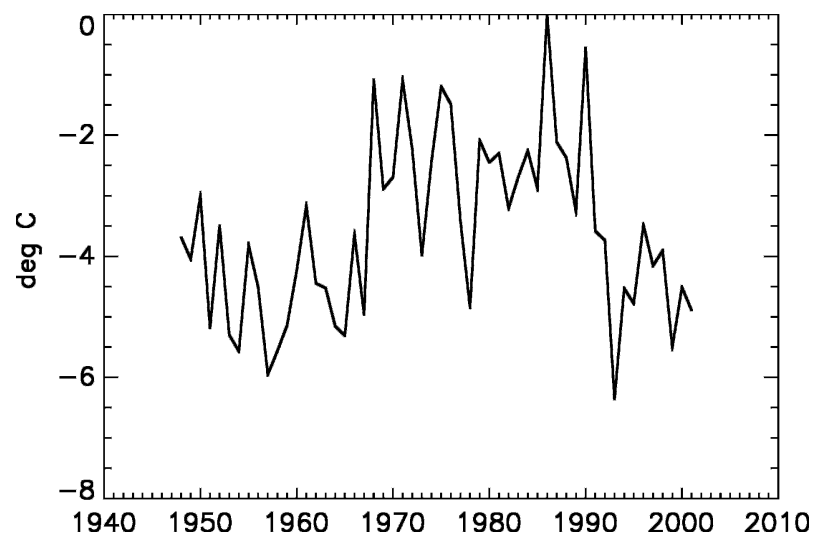

FIG. D1. Annually averaged $T_{\min }\left({ }^{\circ} \mathrm{C}\right.$, relative to 1961-90) at Kljuci in eastern Siberia $\left(56^{\circ} \mathrm{N}, 161^{\circ} \mathrm{E}\right)$ on nights with low (bottom terce) $850-\mathrm{hPa}$ relative humidity relative to nights with high (top terce) relative humidity. The discontinuities in the late 1960s and early 1990s are not evident in the corresponding analysis of $T_{\min }$ on calm relative to windy nights (not shown). 


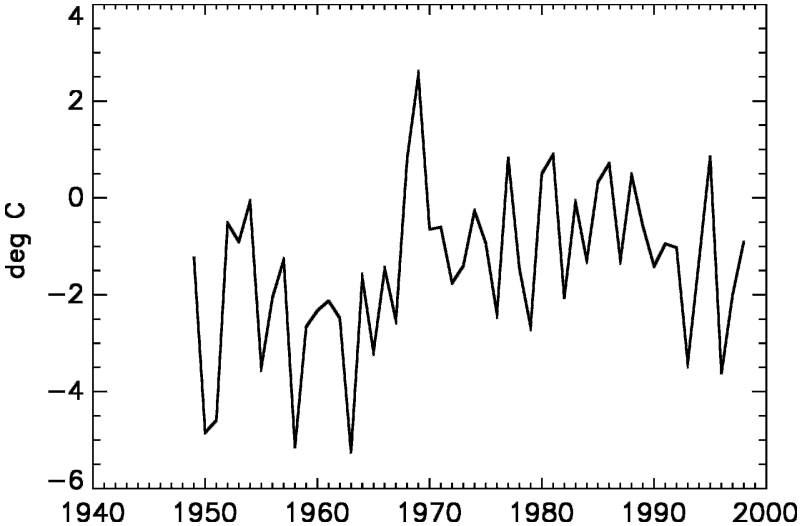

FIG. D2. Annually averaged $T_{\min }\left({ }^{\circ} \mathrm{C}\right.$, relative to 1961-90) at Fairbanks, AK, on nights with low (bottom terce) 850-hPa relative humidity relative to high (top terce) relative humidity. The relative change of $T_{\min }$ appears as a discontinuity in the late 1960s and the trend correlation is only 0.32 , as against 0.46 in Fig. 2.

served cloud cover data may be of insufficient quality to verify the $\mathrm{RH}_{850}$ data.

\section{REFERENCES}

Arnfield, A. J., 2003: Two decades of urban climate research: A review of turbulence, exchanges of energy and water, and the urban heat island. Int. J. Climatol., 23, 1-26.

Dai, A., A. D. DelGenio, and I. Y. Fung, 1997: Clouds, precipitation and temperature range. Nature, 386, 665-666.

Diggle, P. J., K. Y. Liang, and S. L. Zeger, 1999: Analysis of Longitudinal Data. Clarendon Press, 253 pp.

Easterling, D. R., and Coauthors, 1997: Maximum and minimum temperature trends for the globe. Science, 277, 364-367.

Elliott, W. P., and D. J. Gaffen, 1991: On the utility of radiosonde humidity archives for climate studies. Bull. Amer. Meteor. Soc., 72, 1507-1520.

_ R. J. Ross, and B. Schwartz, 1998: Effects on climate records of changes in National Weather Service humidity processing procedures. J. Climate, 11, 2424-2436.

Folland, C. K., and Coauthors, 2001a: Global temperature change and its uncertainties since 1861. Geophys. Res. Lett., 28, 26212624.

$\longrightarrow$, and — 2001b: Observed climate variability and change. Climate Change 2001: The Scientific Basis, J. T. Houghton et al., Eds., Cambridge University Press, 99-181.

GCOS, 2004: Implementation plan for the Global Observing System for Climate in support of the UNFCCC. Global Climate Observing System GCOS-92, WMO Tech. Doc. 1219, 136 pp. [Available online at http://www.wmo.int/web/gcos/gcoshome. html.]

Hansen, J., R. Ruedy, J. Glascoe, and M. Sato, 1999: GISS analysis of surface temperature change. J. Geophys. Res., 104 (D24), 30 997-31 022.

,-- M. Sato, M. Imhoff, W. Lawrence, D. Easterling, T. Peterson, and T. Karl, 2001: A closer look at United States and global surface temperature change. J. Geophys. Res., 106 (D20), 23 947-23 963.

Horton, E. B., C. K. Folland, and D. E. Parker, 2001: The changing incidence of extremes in worldwide and Central England temperatures to the end of the twentieth century. Climatic Change, 50, 267-295.

Hurrell, J. W., and H. van Loon, 1997: Decadal variations in climate associated with the North Atlantic Oscillation. Climatic Change, 36, 301-326.

Johnson, G. T., T. R. Oke, T. J. Lyons, D. G. Steyn, I. D. Watson, and J. A. Voogt, 1991: Simulation of surface urban heat islands under "ideal" conditions at night. Part 1: Theory and tests against field data. Bound.-Layer Meteor., 56, 275-294.

Jones, P. D., and A. Moberg, 2003: Hemispheric and large-scale surface air temperature variations: An extensive revision and an update to 2001. J. Climate, 16, 206-223.

_, P. Ya. Groisman, M. Coughlan, N. Plummer, W. C. Wang, and T. R. Karl, 1990: Assessment of urbanization effects in time series of surface air temperature over land. Nature, $\mathbf{3 4 7}$, 169-172.

, T. J. Osborn, and K. R. Briffa, 1997: Estimating sampling errors in large-scale temperature averages. J. Climate, 10, 2548-2568.

_, E. B. Horton, C. K. Folland, M. Hulme, D. E. Parker, and T. A. Basnett, 1999: The use of indices to identify changes in climate extremes. Climatic Change, 42, 131-149.

Kalnay, E., and M. Cai, 2003: Impact of urbanization and land-use change on climate. Nature, 423, 528-531.

_ and Coauthors, 1996: The NCEP/NCAR 40-Year Reanalysis Project. Bull. Amer. Meteor. Soc., 77, 437-471.

Karl, T. R., C. N. Williams, P. J. Young, and W. M. Wendland, 1986: A model to estimate the time of observation bias associated with monthly mean maximum, minimum and mean temperatures for the United States. J. Climate Appl. Meteor., 25, $145-160$.

Klein Tank, A. M. G., and Coauthors, 2002: Daily dataset of 20th-century surface air temperature and precipitation series for the European Climate Assessment. Int. J. Climatol., 22, 1441-1453.

Laursen, E. V., 2002: Observed daily precipitation, maximum temperature and minimum temperature from Ilulissat and Tasiilaq, 1873-2000, version 2. Danish Meteorological Institute Tech. Rep. 02-15, 10 pp.

Lin, X., K. G. Hubbard, E. A. Walter-Shea, and J. R. Brandle, 2001: Some perspectives on recent in situ air temperature observations: Modeling the microclimate inside the radiation shields. J. Atmos. Oceanic Technol., 18, 1470-1484.

Magee, N., J. Curtis, and G. Wendler, 1999: The urban heat island at Fairbanks, Alaska. Theor. Appl. Climatol., 64, 39-47.

Manley, G., 1974: Central England temperatures: Monthly means 1659 to 1973. Quart. J. Roy. Meteor. Soc., 100, 389-405.

Manton, M. J., and Coauthors, 2001: Trends in extreme daily rainfall and temperature in southeast Asia and the South Pacific: 1961-1998. Int. J. Climatol., 21, 269-284.

Mason, P. J., and Coauthors, 2003: The second report on the adequacy of the Global Observing Systems for Climate in support of the UNFCCC. Global Climate Observing System GCOS-82, WMO Tech. Doc. 1143, 74 pp.

Parker, D. E., 1994: Effects of changing exposure of thermometers at land stations. Int. J. Climatol., 14, 1-31.

, 2004: Large-scale warming is not urban. Nature, 432, 290.

— 2000. Weather, 56, 255-267.

- T. P. Legg, and C. K. Folland, 1992: A new daily central England temperature series. Int. J. Climatol., 12, 317-342. 
Peterson, T. C., 2003: Assessment of urban versus rural in situ surface temperatures in the contiguous United States: No difference found. J. Climate, 16, 2941-2959.

— data are important. J. Climate, 18, 2637-2646.

— - K. P. Gallo, J. Lawrimore, A. Huang, and D. A. McKittrick, 1999: Global rural temperature trends. Geophys. Res. Lett., 26, 329-332.

Razuvaev, V. N., E. G. Apasova, and R. A. Martuganov, cited 1993: Daily temperature and precipitation data for 223 USSR stations. ORNL/CDIAC-56, NDP-040, ESD Publication 4194, Carbon Dioxide Information Data Center, Oak Ridge National Laboratory, Oak Ridge, TN. [Available online at http://cdiac.ornl.gov/ftp/ndp040/ndp040.txt.]

Simmons, A. J., and Coauthors, 2004: Comparison of trends and low-frequency variability in CRU, ERA-40, and NCEP/ NCAR analyses of surface air temperature. J. Geophys. Res., 109, D24115, doi:10.1029/2004JD005306.

Trenberth, K. E., 2004: Rural land-use change and climate. Nature, 427, 213.

Vincent, L. A., X. Zhang, B. R. Bonsal, and W. D. Hogg, 2002: Homogenization of daily temperatures over Canada. J. Climate, 15, 1322-1334.

Vose, R. S., T. R. Karl, D. R. Easterling, C. N. Williams, and M. J. Menne, 2004: Impact of land-use change on climate. Nature, 427, 213-214.

Zhou, L., R. E. Dickinson, Y. Tian, J. Fang, Q. Li, R. K. Kaufmann, C. J. Tucker, and R. B. Myneni, 2004: Evidence for a significant urbanization effect on climate in China. Proc. Natl. Acad. Sci. USA, 101, 9540-9544. 